\title{
PENGARUH DOSIS AMPAS TAHU DAN PUPUK AGROBOST TERHADAP PERTUMBUHAN DAN HASIL TANAMAN JAGUNG MANIS Zea mays saccharata Sturt.
}

\author{
(Efect Of Dosage Tofu Dregs and Agrobost Fetilezer to Growth and Yield Of Sweet \\ Corn Crops Zea mays saccharat Sturt.)
}

\author{
Fathul Rizal $^{1}$, Bakhtiar ${ }^{1}$, Jumini $^{{ }^{*}}$ \\ ${ }^{1}$ Program Studi Agroteknologi, Fakultas Pertanian, Universitas Syiah Kuala
}

\begin{abstract}
Abstrak. Penelitian ini bertujuan untuk mengetahui pengaruh dosis ampas tahu dan konsentrasi pupuk agrobost serta interaksi antara terhadap pertumbuhan dan hasil tanaman jagung manis. Penelitian ini dilaksanakan di Kebun Percobaan dan Laboratorium Fisiologi Tumbuhan Fakultas Pertanian Universitas Syiah Kuala Banda Aceh pada bulan Januari sampai April 2018. Rancangan yang digunakan adalah Rancangan Acak Kelompok pola faktorial 4 x 3 dengan 3 kali ulangan. Faktor pertama adalah dosis ampas tahu dan faktor kedua adalah konsentrasi pupuk Agrobost. Peubah yang diamati yaitu tinggi tanaman, diameter batang, panjang tongkol berkelobot, panjang tongkol tanpa kelobot, berat tongkol berkelobot, berat tongkol tanpa kelobot dan potensi hasil. Hasil penelitian menunjukkan bahwa dosis ampas tahu berpengaruh sangat nyata terhadap tinggi tanaman 45 HST, diameter batang umur 30 HST dan 45 HST, panjang tongkol berkelobot, tanpa kelobot, berat tongkol berkelobot dan tanpa kelobot, potensi hasil berkelobot dan tanpa kelobot, berpengaruh nyata terhadap tinggi tanaman 15 HST dan 30 HST serta diameter batang 15 HST. Perlakuan konsentrasi pupuk Agrobost berpengaruh sangat nyata terhadap diameter batang 30 dan 45 HST, panjang tongkol berkelobot, panjang tongkol tanpa kelobot, berat tongkol berkelobot, berat tongkol tanpa kelobot, potensi hasil berkelobot dan potensi hasil tanpa kelobot. Namun tidak berpengaruh nyata terhadap tinggi 15 dan 45 HST serta diameter 15 HST. Tidak terdapat interaksi yang nyata antara dosis ampas tahu dan konsentrasi pupuk Agrobost terhadap semua peubah pengamatan. Perlakuan dosis ampas tahu 10, 20 dan 30 ton/ha memberikan pertumbuhan dan hasil jagung manis yang sama baiknya, namun dari segi ekonomis 10 ton/ha lebih efektif untuk digunakan. Perlakuan pupuk agrobost yang lebih baik di jumpai pada konsentrasi $15 \mathrm{ml} / \mathrm{l}$ air yang memberikan pertumbuhan dan hasil jagung manis dibandingkan dengan kontrol dan $30 \mathrm{ml} / \mathrm{l}$ air.
\end{abstract}

\section{Kata kunci : Ampas Tahu, Agrobost, Jagung Manis}

\begin{abstract}
Abstrack. This research was conducted to know wheter the effect of dosage tofu dregs and agrobost fertilizer consentration and interaction between both of it to growth and yield of sweet corn crops. This research did at. Experimental Farm and Plant Phaysiology Laboratory of Syiah Kuala University, Banda Aceh, on January to April 2018. The design was used Randomized Block Design (RBD) 4 × 3 factorial pattern with 3 times repeated. The first factor was dosage of tofu dregs (D) and the second factor was agrobost consentration (T). The observed variables were plant height, stem diameter, length of cob weighted, length of cob without weighted, weight of cob weighted, weight of cob weight without weight and yield potential. The results showed that dosage of tofu dregs very significant effect on plant height of 45 DAP, stem diameter of 30 DAP and 45 DAP, length of cob weighted, length of cob without weighted, weight of cob weighted and weight of cob without weighted, yield potency of cob weighted and yield potency of cob without weighted. The significant effect on plant height of 15 DAP and 30 DAP and stem diameter of 15 DAP. Agrobost fertilizer concentration was very significant effect on stem diameter of 30 and 45 DAP, length of cob weighted, length of cob without weighted, weight of cob weighted, weight of cob without weighted, yield potency of cob weighted and yield potency without weighted. However, no significant effect on the plant height of 15 and 45 DAP and the diameter of 15 DAP. There were no interaction between dregs of tofu and Agrobost fertilizer concentration on all observation parameters. The treatment of dregs tofu 10,20 and 30 tons/ha the same growth and yield of sweet corn, but terms of economical 10 tons/ha is more effective to use. The treatment of agrobost fertilizer was found better at concentration of 15 $\mathrm{ml} / \mathrm{l}$ water which gave growth and sweet corn yield compared to the control and $30 \mathrm{ml} / \mathrm{l}$ water.
\end{abstract}

Keyword: Dregs of Tofu, agrobost, Sweet Corn 


\section{PENDAHULUAN}

\section{Latar Belakang}

Jagung manis merupakan komoditas pertanian yang memiliki nilai jual tinggi sehingga mengakibatkan permintaan jagung meningkat. Produksi jagung manis di tahun 2014 sebanyak 19 juta t/ha dan terjadi peningkatan di tahun 2015 sebanyak 20,67 juta t/ha (Kementerian Pertanian, 2015). Produksi jagung manis di Aceh di tahun 2014 sekitar 202.318 t dan terjadi peningkatan di tahun 2015 sebesar 205.125 t/ha. Tingkat produksi jagung manis meningkat setiap tahunnya, namun jumlah permintaan pasar terhadap jagung manis menurun sebanyak $17,25 \%$ /tahun, sedangkan untuk impor jagung manis mengalami peningkatan sebanyak 6,26\% (BPS, 2015).

Unsur hara yang sangat dibutuhkan oleh tanaman jagung manis yaitu unsur hara makro dan mikro. Pemupukan adalah usaha pemberian atau penambahan unsur hara yang diperlukan tanaman untuk meningkatkan pertumbuhan, kualitas dan produksi hasil dari tanaman. Ketersediaan unsur hara di dalam tanah rendah maka perlunya dilakukan pemupukan, karena terjadi kehilangan unsur hara melalui pencucian, pengangkutan pada waktu panen, dan adanya keinginan untuk memaksimalkan keuntungan. Manfaat dari pemupukan yaitu untuk meningkatkan hasil kualitatif maupun kuantitatif hasil panen (Prahasta, 2009).

Limbah tahu yang berasal dari industiri pangan dapat dimanfaatkan sebagai pupuk organik (Setyowati, 2001). Nuraini dan Puspitasari (2004) mengemukakan bahwa timbunan ampas tahu yang dibuang ke lingkungan belum banyak dimanfaatkan sebagai bahan penyubur tanah padahal mempunyai potensi karena mengandung protein yang cukup tinggi. Kandungan yang terdapat dalam ampas tahu $\mathrm{N}, \mathrm{P}, \mathrm{K}, \mathrm{Ca}, \mathrm{Mg}$, dan $\mathrm{C}$ organik yang dapat meningkatkan kesuburan tanah. Hingga saat ini, masih sangat banyak limbah tahu yang diterlantarkan begitu saja tanpa diolah dan dimanfaatkan sebagai bahan organik. Sehubungan dengan uraian di atas, maka perlu diteliti pengaruh limbah tahu untuk memperbaiki sifat biologi dan kimia tanah serta hasil tanaman jagung manis.

Karakteristik sifat fisik, kondisi fisik ampas tahu selama penyimpanan sampai jam ke12 adalah berwarna putih, bau khas kedelai, tekstur halus dan mawur. Namun setelah lebih dari 12 jam, ampas tahu berubah menjadi kusam, berbau agak asam sampai asam dan memiliki lendir serta jamur yang terlihat jelas melalui pengamatan visual. Dari hasil karakterisasi sifat kimia dan mikrobiologi ampas tahu, diketahui bahwa ampas tahu memiliki kadar pangan 2,16 \% (berdasarkan berat basah), kadar air 86,8 \%, kandungan total mikroba lebih dari batas aman konsumsi, yaitu lebih dari 1 x $106 \mathrm{cfu} / \mathrm{g}$, kandungan E. coli lebih dari $1100 \mathrm{apm} / \mathrm{g}$ (batas aman $10 \mathrm{apm} / \mathrm{g}$ ), tidak mengandung Salmonella sp (BPTP, 2015).

Pupuk hayati merupakan pupuk yang mengadug mikroba yang apat memperbaiki kesuburan tanah, misalnya mikroba pelarut fosfat, rhizobium, cendawan mikoriza dan mikroba lainnya. Penambahan bakteri perangsang pertumbuhan tanaman dapat merangsang pertumbuhan akar tanaman sehingga penyerapan hara nitrogen $(\mathrm{N})$ dan $(\mathrm{P})$. Penambahan mikroba pelarut fosfat mampu meningkatkan ketersedian hara fosfor $(\mathrm{P})$ di dalam tanah fosfar (Hasibuan, 2006).

Pupuk agrobost adalah salah satu pupuk hayati yang memiliki keistimewaan yaitu dapat mengurangi pupuk kimia sampai $50 \%$ atau sekaligus dapat meningkatkan produktivitas. Beberapa mikroba yang terdapat dalam pupuk agrobost yang dibutuhkan untuk mengurai bahan organik pada tanah yaitu Azospirillum, Azotobacter, Lactobacillus, Enzim Selulase, Mikroba Pendegradasi Selulasa, Mikroba Pelarut P, dan Hormon Tumbuh Indole Acetic Acid. Mikroba dan enzim yang terdapat di atas mampu menghematkan penggunaan 
pupuk kimia serta mampu bekerja secara maksimal di dalam tanah (Agro Dahlia Profitmas, 2008).

Hasil penelitian Hamzah et al. (2008) pada tanaman jagung ketan (Zea mays certain) menunjukkan bahwa pupuk Agrobost dengan konsentrasi $30 \mathrm{cc} / 1$ air diperoleh hasil tertinggi terhadap pengamatan diameter batang, jumlah daun, tinggi tanaman, panjang dan berat tongkol, sedangkan pupuk humagold serta interaksi Agrobost dan humagold belum memberikan pengaruh yang nyata atau sangat nyata pada semua parameter pengamatan.

Berdasarkan permasalahan diatas perlu dilakukan penelitian tentang pengaruh dosis ampas tahu dan pupuk agrobost terhadap pertumbuhan dan hasil tanaman jagung manis.

\section{Rumusan Masalah}

1. Apakah ada pengaruh dosis ampas tahu terhadap pertumbuhan dan hasil tanaman jagung manis?

2. Apakah ada pengaruh konsentrasi pupuk grobost terhadap pertumbuhan dan hasil tanaman jagung manis?

3. Apakah ada interaksi yang nyata antara ampas tahu dengan pupuk agrobost terhadap pertumbuhan dan hasil tanaman jagung manis?

\section{TujuanPenelitian}

1. Untuk mengetahui pengaruh perlakuan dosis ampas tahu terhadap pertumbuhan dan hasil tanaman jangung manis.

2. Untuk mengetahui pengaruh konsentrasi pupuk agrobost terhadap pertumbuhan dan hasil tanaman jagung manis.

3. Untuk mengetahui ada tidaknya interaksi antara dosis ampas tahu dengan pupuk agrobost terhadap pertumbuhan dan hasil tanaman jagung manis.

\section{Hipotesis}

1. Perlakuan dosis ampas tahu berpengaruh terhadap pertumbuhan dan hasil tanaman jagung manis.

2. Perlakuan konsentrasi pupuk agrobost berpengaruh terhadap pertumbuhan dan hasil tanaman jagung manis.

3. Terdapat interaksi antara perlakuan dosis ampas tahu dengan konsentrasi pupuk agrobost terhadap pertumbuhan dan hasil tanaman jagung manis.

\section{METODE PENELITIAN}

\section{Tempat dan Waktu Penelitia}

Penelitian ini dilaksanakan di Kebun Percobaan Fakultas Pertanian Universitas Syiah Kuala Darussalam Banda Aceh mulai dari Januari sampai April 2018. dengan ketinggian tempat 0,80 meter di atas permukaan laut dan jenis tanah Entisol.

\section{Bahan dan Alat}

Bahan yang digunakan dalam penelitian ini adalah benih jagung manis varietas Bonanza $200 \mathrm{~g}$, pupuk organik Agrobost sebanyak 10 liter, insektisida Topban, ampas tahu $324 \mathrm{~kg}$, pupuk non organik yang digunakan untuk penelitian ini $1 / 2$ dosis anjuran, yaitu SP-36 sebanyak 2,43 kg, $\mathrm{KCl}$ sebanyak 2,43kg dan Urea sebanyak 7,29 kg.

Alat-alat yang digunakan dalam penelitian ini antara lain cangkul, parang, timbangan analitik, meteran, pancang, tali rafia, tugal, selang air, gembor, sprayer mini, pamplet, jangka sorong, gunting, kamera dan alat tulis. 


\section{Rancangan Percobaan}

Penelitian di lakukan dengan menggunakan Rancangan Acak Kelompok faktorial dengan tiga ulangan, terdiri dari dua fakor yang diteliti yaitu:

Faktor pertama yaitu dosis ampas tahu (D) terdiri dari 4 taraf yaitu :

$\mathrm{D}_{0} \quad=$ Kontrol

$\mathrm{D}_{1}=10 \mathrm{t} / \mathrm{hektar}=6 \mathrm{~kg} / \mathrm{plot}$

$\mathrm{D}_{2}=20 \mathrm{t} / \mathrm{hektar}=12 \mathrm{~kg} / \mathrm{plot}$

$\mathrm{D}_{3}=30 \mathrm{t} / \mathrm{hektar}=18 \mathrm{~kg} / \mathrm{plot}$

Faktor kedua yaitu konsentrasi pupuk Agrobost (T) terdiri dari 3 taraf yaitu:

$\mathrm{T}_{0} \quad=$ Kontrol

$\mathrm{T}_{1}=15 \mathrm{ml} / \mathrm{l}$ air

$\mathrm{T}_{2}=30 \mathrm{ml} / \mathrm{l}$ air

\section{Peubah yang diamati}

Tinggi tanaman $(\mathrm{cm})$

Pengamatan tinggi tanaman dilakukan masing-masing pada 5 tanaman sampel/plot saat tanaman berumur 15, 30 dan 45 HST, dilakukan dengan cara mengukur mulai pangkal batang sampai pada ujung daun tertinggi.

\section{Diameter batang (mm)}

Pengamatan diameter batang dilakukan pada umur 15, 30 dan 45 HST dengan cara mengukur pada bagian pangkal batang tanaman jagung dengan menggunakan alat jangka sorong.

\section{Panjang tongkol dengan kelobot $(\mathrm{cm})$}

Pengamatan panjang tongkol berkelobot dilakukan dengan mengukur panjang tongkol dari pangkal sampai ujung tongkol, dilakukan pada saat panen.

\section{Panjang tongkol tanpa kelobot $(\mathbf{c m})$}

Pengamatan panjang tongkol tanpa kelobot dilakukan dengan cara mengukur panjang tongkol yang dipanen pada setiap satu tanaman menggunakan meteran, sebelum diamati kelobot dikupas.

\section{Berat tongkol dengan kelobot basah (g)}

Pengamatan berat tongkol berkelobot dilakukan dengan cara menimbang tongkol yang dipanen pada setiap satu tanaman.

\section{Berat tongkol tanpa kelobot basah (g)}

Pengamatan ini dilakukan dengan cara menimbang tongkol yang dipanen pada setiap satu tanaman setelah dikupas.

\section{Potensi hasil basah (ha)}

Potensi hasil ha $\mathrm{ha}^{-1}$ diamati dengan mengkonversikan berat tongkol jagung tanpa kelobot/tanaman dengan menggunakan rumus :

$$
\text { Potensi hasil (ton } \left./ \mathrm{ha}^{-1}\right)=\frac{\text { Luas lahan/ha }}{\text { Jarak tanam }} \times \text { berat tongkol }
$$




\section{HASIL DAN PEMBAHASAN}

\section{Pengaruh Dosis Ampas Tahu Terhadap Pertumbuhan dan Hasil Tanaman Jagung Manis}

Tabel 1. Rata-rata pertumbuhan dan hasil tanaman jagung manis akibat perlakuan dosis ampas tahu

\begin{tabular}{|c|c|c|c|c|c|c|}
\hline \multirow{2}{*}{\multicolumn{2}{|c|}{ Parameter yang diamati }} & \multicolumn{4}{|c|}{ Dosis Ampas Tahu (t/ha) } & \multirow{3}{*}{$\begin{array}{l}\text { BNJ } \\
0,05 \\
5,47\end{array}$} \\
\hline & & \multirow{2}{*}{$\begin{array}{r}\left(\mathrm{D}_{0}\right) 0 \\
45,49 \mathrm{a}\end{array}$} & \multirow{2}{*}{\begin{tabular}{|l}
$\left(D_{1}\right) 10$ \\
$49,99 a b$
\end{tabular}} & \multirow{2}{*}{$\begin{array}{l}\left(\mathrm{D}_{2}\right) 20 \\
49,61 \mathrm{ab}\end{array}$} & \multirow{2}{*}{$\begin{array}{l}\left(\mathrm{D}_{3}\right) 30 \\
51,08 \mathrm{~b}\end{array}$} & \\
\hline & $15 \mathrm{HST}$ & & & & & \\
\hline $\begin{array}{l}\text { Tinggi Tanaman } \\
(\mathrm{cm})\end{array}$ & $30 \mathrm{HST}$ & $127,43 \mathrm{a}$ & $134,21 \mathrm{a}$ & 137,95 a & $137,67 \mathrm{a}$ & 10,68 \\
\hline \multirow{4}{*}{$\begin{array}{l}\text { Diameter Batang } \\
\quad(\mathrm{cm})\end{array}$} & 45 HST & 216,23 a & $232,45 \mathrm{~b}$ & $239,03 \mathrm{~b}$ & $239,27 \mathrm{~b}$ & 15,38 \\
\hline & 15 HSPT & 8,29 a & $9,36 \mathrm{~b}$ & $9,55 \mathrm{~b}$ & $9,48 \quad b$ & 1,21 \\
\hline & $30 \mathrm{HSPT}$ & 25,42 a & $27,13 a b$ & $28,21 \mathrm{~b}$ & $27,64 \mathrm{~b}$ & 1,98 \\
\hline & 45 HSPT & 27,84 a & $29,15 \mathrm{~b}$ & $30,01 \mathrm{~b}$ & $30,09 \mathrm{~b}$ & 1,12 \\
\hline \multicolumn{2}{|c|}{ Berat Tongko Berkelobot Basah } & $432,08 \mathrm{a}$ & $497,80 \mathrm{~b}$ & $528,59 \mathrm{~b}$ & $502,92 \mathrm{~b}$ & 39,14 \\
\hline \multicolumn{2}{|c|}{ Berat Tongkol Tanpa Kelobot Basah } & 371,26 a & $428,06 \mathrm{~b}$ & $458,42 \mathrm{~b}$ & $437,73 \mathrm{~b}$ & 38,85 \\
\hline \multicolumn{2}{|c|}{ Panjang Tongkol Berkelobot } & 25,36 a & $26,82 \mathrm{~b}$ & $27,36 \mathrm{~b}$ & $26,97 \mathrm{~b}$ & 0,83 \\
\hline \multicolumn{2}{|c|}{ Panjang Tongkol Tanpa Kelobot } & $21,50 \mathrm{a}$ & $22,56 \mathrm{~b}$ & $23,14 \mathrm{~b}$ & $22,67 \mathrm{~b}$ & 0,62 \\
\hline \multicolumn{2}{|c|}{ Potensi Hasil Berkelobot } & $12,34 \mathrm{a}$ & $14,22 \mathrm{ab}$ & $15,36 \mathrm{~b}$ & $14,36 \mathrm{~b}$ & 1,12 \\
\hline \multicolumn{2}{|c|}{ Potensi Hasil Tanpa Kelobot } & $10,60 \mathrm{a}$ & $12,21 \mathrm{~b}$ & $13,07 \mathrm{~b}$ & $12,50 \mathrm{~b}$ & 1,10 \\
\hline
\end{tabular}

Keterangan : Angka yang diikuti oleh huruf yang sama pada baris yang sama berbeda tidak nyata pada taraf 0.05 (Uji BNJ)

Tabel 1 menunjukkan bahwa tanaman jagung manis pada umur 15 HST lebih tinggi dijumpai pada dosis ampas tahu 30 t/ha yang berbeda nyata dengan kontrol namun tidak berbeda nyata dengan dosis 10 dan 20 t/ha. Selanjutnya pada umur 30 HST tanaman jagung manis lebih tinggi di jumpai pada dosis 20 t/ha yang tidak berbeda nyata dengan perlakuan lainnya. Sedangkan pada umur 45 HST tanaman jagung manis lebih tinggi dijumpai pada dosis ampas tahu $30 \mathrm{t} / \mathrm{ha}$ yang tidak berbeda nyata dengan dosis ampas tahu 10 dan $20 \mathrm{t} / \mathrm{ha}$ namun berbeda nyata dengan kontrol.

Pada diameter batang tanaman jagung manis pada umur 15 HST lebih tinggi dijumpai pada dosis ampas tahu 10 t/ha yang berbeda tidak nyata dengan dosis ampas tahu 20 dan 30 t/ha namun berbeda nyata dengan kontrol. Selanjutnya diameter batang tanaman jagung manis pada umur 30 HST lebih tinggi dijumpai pada dosis ampas tahu 20 t/ha yang tidak berbeda nyata dengan dosis ampas tahu 10 dan 30 t/ha namun berbeda nyata dengan kontrol. Sedangkan diameter batang tanaman jagung manis pada umur 45 HST lebih tinggi dijumpai pada dosis ampas tahu 30 t/ha yang tidak berbeda nyata dengan dosis ampas tahu 10 dan 20 $\mathrm{t} / \mathrm{ha}$ namun berbeda nyata dengan kontrol.

Pada berat tongkol berkelobot, berat tongkol tanpa kelobot, panjang tongkol berkelobot, panjang tongkol tanpa kelobot, potensi hasil berkelobot dan potensi hasil tanpa kelobot lebih tinggi dijumpai pada dosis ampas tahu $20 \mathrm{t} / \mathrm{ha}$ yang tidak berbeda nyata dengan dosis ampas tahu 10 dan 30 t/ha namun berbeda nyata dengan kontrol. 


\section{Pengaruh Pupuk Agrobost Terhadap Pertumbuhan dan Hasil Tananaman Jagung Manis}

Tabel 2. Rata-rata pertumbuhan dan hasil tanaman jagung manis akibat perlakuan dosis konsentrasi pupuk agrobost

\begin{tabular}{|c|c|c|c|c|c|}
\hline \multirow{2}{*}{\multicolumn{2}{|c|}{ Parameter yang diamati }} & \multicolumn{3}{|c|}{ Konsentrasi Pupuk Agrobost (ml/l) } & \multirow{2}{*}{$\begin{array}{l}\text { BNJ } \\
0,05\end{array}$} \\
\hline & & $\left(\mathrm{T}_{0}\right) 0$ & $\left(\mathrm{~T}_{1}\right) 15$ & $\left(T_{2}\right) 30$ & \\
\hline \multirow{3}{*}{$\begin{array}{c}\text { Tinggi } \\
\text { Tanaman }(\mathrm{cm})\end{array}$} & 15 HSPT & 47,80 & 49,43 & 49.90 & - \\
\hline & 30 HSPT & $128,69 \mathrm{a}$ & $136,84 \mathrm{ab}$ & $137,41 \mathrm{~b}$ & 8,36 \\
\hline & 45 HSPT & 229,21 & 231,41 & 234,60 & - \\
\hline \multirow{3}{*}{$\begin{array}{c}\text { Diameter } \\
\text { Batang }(\mathrm{cm})\end{array}$} & 15 HSPT & 8,91 & 9,41 & 9,18 & - \\
\hline & $30 \mathrm{HSPT}$ & $25,90 \mathrm{a}$ & $27,08 \mathrm{ab}$ & $28,32 \mathrm{~b}$ & 1,55 \\
\hline & 45 HSPT & 28,08 a & $29,71 \mathrm{~b}$ & $30,04 \mathrm{~b}$ & 0,88 \\
\hline \multicolumn{2}{|c|}{ Berat Tongkol Berkelobot } & $468,01 \mathrm{a}$ & $492,43 \mathrm{ab}$ & $510,60 \mathrm{~b}$ & 30,65 \\
\hline \multicolumn{2}{|c|}{ Berat Tongkol Tanpa Kelobot } & $401,01 \mathrm{a}$ & $426,14 \mathrm{ab}$ & $444,47 \mathrm{~b}$ & 30,41 \\
\hline \multicolumn{2}{|c|}{ Panjang Tongkol Berkelobot } & 26,16 a & $26,68 \mathrm{ab}$ & $27,05 \mathrm{~b}$ & 0,65 \\
\hline \multicolumn{2}{|c|}{ Panjang Tonkol Tanpa Kelobot } & 22,03 a & $22,55 \mathrm{~b}$ & $22,81 \quad b$ & 0,48 \\
\hline \multicolumn{2}{|c|}{ Potensi Hasil Berkelobot } & 13,37 a & $14,06 \mathrm{ab}$ & $14,58 \mathrm{~b}$ & 0,88 \\
\hline \multicolumn{2}{|c|}{ Potensi Hasil Tanpa Kelobot } & $11,42 \mathrm{a}$ & $12,17 \mathrm{ab}$ & $12,69 \mathrm{~b}$ & 0,86 \\
\hline
\end{tabular}

Keterangan : Angka yang diikuti oleh huruf yang sama pada baris yang sama berbeda tidak nyata pada taraf 0,05 (Uji BNJ).

Tabel 3 menunjukan bahwa tinggi tanaman jagung manis pada umur 30, diameter batang 30 dan 45, berat tongkol berkelobot, berat tongkol tanpa kelobot, panjang tongkol berkelobot, panjang tongkol tanpa kelobot, potensi hasil berkelobot dan potensi tanpa kelobot lebih tinggi dijumpai pada konsentrasi $30 \mathrm{ml} / \mathrm{l}$ air yang tidak berbeda nyata dengan konsentrasi $15 \mathrm{ml} / \mathrm{l}$ air namun berbeda nyata dengan kontrol.

\section{Pembahasan}

\section{Pengaruh Dosis Ampas Tahu Terhadap Pertumbuhan dan Hasil Tanaman Jagung Manis}

Hasil penelitian menunjukkan bahwa pertumbuhan dan hasil tanaman jagung manis pada perlakuan dosis ampas tahu 10, 20 dan $30 \mathrm{t} /$ ha tidak menunjukkan perbedaan yang nyata, namun di tinjau dari segi ekonomis 10 t/ha lebih efektif untuk di gunakan bisa dilihat pada parameter tinggi tanaman 15, 30, 45 HST, diameter batang 15, 30, 45 HST, berat tongkol berkelobot basah, berat tongkol tanpa kelobot basah, panjang tongkol berkelobot, panjang tongkol tanpa kelobot, potensi hasil berkelobot dan potensi hasil tanpa kelobot. Hal ini diduga pada pemberian dosis ampas tahu 10 t/ha sudah dapat memperbaiki sifat fisik, biologis,dan kimia tanah karena pada ampas tahu memiliki unsur hara makro seperti $\mathrm{N}, \mathrm{P}, \mathrm{K}$ dan $\mathrm{C}$ organik yang berperan untuk meningkatkan pertumbuhan dan hasil tanaman jagung. Djohana (1989) menyatakan bahwa pemberian pupuk harus dalam jumlah yang tepat sehingga diperoleh hasil pemupukan yang optimal. Penelitian Bagus et al. (1997) ketersediaan unsur hara makro dan $\mathrm{C}$ organik dapat mempengaruhi pertumbuhan dan hasil tanaman jagung manis. Hakim et al. (1986) menyatakan bahwa fosfor, kalium dan nitrogen yang merupakan suatu pembatas, karena unsur hara tersebut yang di butuhkan dalam jumlah banyak bagi tanaman. Kalium berfungsi untuk memperbesar diameter batang, serta memiliki peranan pada jaringan xilem dalam penyerapan unsur hara pada tanah.

Lebih lanjut Lakitan (1996) bahwa komponen dari berbagai produk bahan organik di dalam tanah sebagian besar diminimalisir, terutama persenyawaan nitrogen dan fosfat, sebagian lagi dari unsur organik itu ditransfer menjadi humus. Bahan organik yang banyak tentu memberikan hasil yang banyak pula, karena tanaman menyerap unsur hara sesuai 
dengan kebutuhannya. kandungan hara yang terdapat dalam ampas tahu berpengaruh terhadap proses metabolisme tanaman sehingga pertumbuhan vegetatif dan generatif tanaman cukup optimal. Hal ini sesuai dengan Setyowati (2011) menyatakan bahwa limbah tahu selain mengandung $\mathrm{N}$ dalam bentuk anorganik dan organik yang dapat dipergunakan pada waktu cepat dan juga waktu yang lama.

Menurut penelitian Ainurrahmi (2008) yang menunjukkan bahwa pemberian limbah tahu padat menghasilkan perubahan sifat kimia dan memperbaiki pertumbuhan tanaman jagung dan bobot kering tanaman lebih baik dibandingkan limbah cair. Hidayani (2014) menyatakan bahwa limbah tahu padat sangat nyata pengaruhnya terhadap bobot tongkol berkelobot, hasil per plot dan hasil per hektar jagung manis serta berpengaruh nyata terhadap panjang dan bobot tongkol tanpa kelobot. Diduga ketersediaan unsur hara nitrogen yang sebagian besar ditransfer pada fase generatif sehingga dapat merangsang terbentuknya tongkol jagung manis yang lebih baik (Nurhayati, 2006).

\section{Pengaruh Pupuk Agrobost terhadap Pertumbuhan dan Hasil Tanaman Jagung Manis}

Berdasarkan penelitian yang sudah dilakukan menunjukan bahwa tanaman jagung manis pada perlakuan konsentrasi pupuk agrobost 15 dan $30 \mathrm{ml} / 1$ air tidak menunjukkan perbedaan yang nyata, konsentrasi agrobost $30 \mathrm{ml} / \mathrm{l}$ air yang lebih efektif dalam meningkatkan pertumbuhan dan hasil jagung manis dapat dilihat pada peubah tinggi tanaman 30 HST, diameter batang 30, 45 HST, berat tongkol berkelobot basah, berat tongkol tanpa kelobot basah, panjang tongkol berkelobot, panjang tongkol tanpa kelobot, potensi hasil berkelot dan potensi hasil tanpa kelobot . Diduga unsur hara yang berada didalam tanah tercukupi akibat adanya mikroba Pseudomonas, Azotobacter, Azospirilium, Lactobacillus mikroba pelarut P, mikroba selulotik yang berasal dari pupuk hayati agrobost yang disumbangkan melalui mikrobia yang terkandung mencukupi kebutuhan tanaman jagung manis, tersedianya unsur hara yang seimbang dalam tanah mampu mempengaruhi pertumbuhan generatif tanaman. Mikrobia yang terkandung dalam pupuk Agrobost mampu menghasilkan kandungan $\mathrm{N}$ yang diserap dari udara sebesar $100 \mathrm{~kg}$, P sebanyak $50 \mathrm{~kg}$, dan $\mathrm{K}$ sebanyak $50 \mathrm{~kg}$, sehingga unsur hara tanaman dapat tercukupi atau bertambah (Nopsagiarti, 2012 ). Adapun senyawa nitrogen digunakan tanaman dalam membentuk asam amino akan diubah menjadi protein. Nitrogen dibutuhkan dalam pembentukan senyawa penting seperti asam nukleat, enzim dan klorofil. Nitrogen dibutuhkan bagi tanaman disetiap proses pertumbuhan, khususnya pada proses pertumbuhan vegetatif dalam pembentukan tunas serta perkembangan batang (Novizan, 2002).

Penelitian Suryawati (2011) menunjukkan bahwa terdapat perbedaan yang nyata terhadap tinggi tanaman, diameter batang, jumlah daun, berat tongkol per sampel, dan berat dan panjang tongkol. Pada perlakuan pupuk agrobost dikarenakan kandungan inokulan campuran yang berbentuk cair mengandung hormon tumbuh dan berbahan aktif penambahan $\mathrm{N} 2$, cepat terserap oleh tanaman jagung sehingga kebutuhan akan unsur penunjang pertumbuhan tanaman jagung terpenuhi. Akumulasi nutrisi yang dihasilkan oleh mikrobia yang terkandung dalam agrobost telah mampu memenuhi kebutuhan tanaman untuk penambahan diameter batang, disamping itu hormon tumbuh dan enzim yang terdapat dalam agrobost akan mendorong aktifitas jaringan meristem.

Dalam pembentukan bagian-bagian vegetatif, tanaman sangat membutuhkan unsur nitrogen. Unsur nitrogen membantu jaringan meristem melakukan pembelahan sel dan pemanjangan sel-sel baru dan protoplasma, sehingga pertumbuhan tanaman berlangsung dengan baik fungsi dari $\mathrm{P}$ yaitu untuk memperkuat serta mempercepat pertumbuhan tanaman muda menjadi tanaman dewasa, membantu pernafasan dan asimilasi, serta sebagai bahan mentah untuk pembentukan sejumlah protein tertentu (Rosmarkam dan Yuwono 2002). 
Pengolahan tanah sebelum penanaman dan penyiraman dilakukan untuk menjaga kelembaban tanah sehingga menyebabkan bakteri Azotobacter sp. yang terkandung dalam pupuk hayati agrobost dapat bekerja maksimal dalam mengikat nitrogen di udara. Mikroba yang berada dalam tanah mampu bekerja secara maksimal pada lingkungan dan kelembaban rendah dengan memiliki tata udara yang baik (Sutanto, 2006).

\section{Interaksi Antara Dosis Ampas Tahu dan Konsentrasi Pupuk Agrobost}

Hasil penelitian menunjukkan bahwa tidak terdapat interaksi yang nyata antara perlakuan dosis ampas tahu dengan konsentrasi pupuk agrobost terhadap semua peubah pengamatan, diduga karena kedua faktor yang digunakan pada penelitian ini belum saling mendukung sehingga interaksi yang ditimbulkan kedua faktor tersebut tidak nyata. Sejalan dengan itu Hanafiah (1991) menyatakan, apabila tidak ada interaksi, berarti pengaruh suatu faktor sama untuk semua taraf faktor lainnya dan sama dengan pengaruh utamanya. Sesuai dengan pernyataan tersebut, maka dapat disimpulkan bahwa kedudukan dari kedua faktor adalah sama-sama mendukung pertumbuhan tanaman, tetapi tidak saling mendukung bila salah satu faktor menutupi faktor lainnya. Lebih lanjut Sutedjo (2001) menjelaskan, bahwa bila salah satu faktor lebih kuat pengaruhnya dari faktor lain sehingga faktor lain tersebut tertutupi dan masing-masing faktor mempunyai sifat yang jauh berbeda pengaruh dan sifat kerjanya, maka tidak akan menghasilkan hubungan nyata dalam mempengaruhi pertumbuhan tanaman.

\section{SIMPULAN DAN SARAN}

\section{Kesimpulan}

Perlakuan dosis ampas tahu berpengaruh terhadap semua peubah yang diamati, dosis yang terbaik dijumpai pada 10 t/ha yang memberikan pertumbuhan dan hasil jagung manis. Perlakuan pupuk agrobost berpengaruh terhadap peubah tinggi tanman $30 \mathrm{HST}$, diameter batang 30 dan 45 HST, berat tongkol berkelobot basah, berat tongkol tanpa kelobot basah, panjang tongkol berkelobot, panjang tongkol tanpa kelobot, potensi hasil berkelobot dan potensi hasil tanpa kelobot pertumbuhan dan hasil tanaman jagung manis yang lebih baik di jumpai pada konsentrasi pupuk agrobost $30 \mathrm{ml} / \mathrm{l}$ air. Tidak terdapat interaksi yang nyata antara dosis ampas tahu dengan konsentrasi pupuk agrobost.

\section{Saran}

Sebaiknya pada tanaman jagung manis dilakukan penelitian dengan dosis ampas tahu 10 t/ha dan pupuk agrobost konsentrasinya lebih dari $30 \mathrm{ml} / \mathrm{l}$ air. 


\section{DAFTAR PUSTAKA}

Ainurrahmi, R. 2008. Pengaruh pemanfaatan limbah tahu terhadap serapan N, P dan K serta pertumbuhan tanaman jagung. Skripsi. Institut Pertanian Bogor. Bogor.

Badan Pusat Statistik. 2015. Tanaman jagung per Provinsi.data.go.id/dataset/tanaman-jagungper-provinsi.

Bagus, J., C. Wardani, I. Arsianti, dan D. Nasrullah. 1997. Alternatif pemanfaatan limbah buangan industri tahu dan tempe sebagai penyubur tanah. LKIP FP UB. Malang.

Djohana, 1989. Pupuk dan Pemupukan. Simpleex. Jakarta.

Hakim, N., Y. Nyakpa., A.M. Lubis., Sutopo., M. Amin., G.B. Hong dan H.H. Bailey. 1986. Dasar - dasar ilmu tanah. Penerbit Universitas Lampung.

Hamzah, S., S. Utami dan M. A.Cholik. 2008. Pengaruh pupuk agrobost dan humagold terhadap pertembuhan dan produksi jagung ketan (Zea maysceratina). Fak. Pertanian UMSU. Medan.

Hanafiah. K. A. 2010. Rancangan Percobaan. Rajawali Pres. Palembang.

Hasibuan, B.E. 2006. Pupuk dan Pemupukan. Fakultas Pertanian, Universitas Sumatera Utara. Medan.

Hidayani, Sufardi dan L. Hakim. 2014. Limbah tahu untuk memperbaiki sifat kimia dan biologi tanah serta hasil tanaman jagung manis (Zea mays var. saccharata sturt. L). Universitas Jabal Ghafur. Sigli.

Kementerian Pertanian. 2015. Outlook komoditas pertanian subsektor tanaman pangan jagung. Pusat data dan Sistem Informasi Pertanian.

Lakitan, B. 1996. Dasar-dasar Fisiologi Tumbuhan. Raja Grafindo Persada. Jakarta.

Novizan. 2002. Petunjuk Pemupukan Efektif. Agromedia. Jakarta

Nopsagiarti, T. 2012. Uji berbagai varietas dan pemberian pupuk agrobost terhadap pertumbuhan dan produksi tanaman padi sawah. Program Studi Agroteknologi, sekolah Tinggi Ilmu Pertanian Swarnadwipa, Teluk Kuantan, Riau. Jurnal Green Suwarnadwipa, 2 (2) : 19-26.

Nurhayati, N. 2006. Pertumbuhan dan hasil jagung manis pada berbagai waktu aplikasi bokashi limbah kulit buah kakao dan pupuk anorganik. J. Agroland, 3 (13): 256 -259.

Nuraini dan Puspitasari, D. 2004. Perbaikan dan Evaluasi Penerapan Sistem Manajemen Mutu. Pada Industri Pengolahan Tahu. Institut Pertanian Bogor, Bogor.

Prahasta. 2009. Agribisnis Jagung. Pustaka Grafika. Bandung.

PT Agro Dahlia Profitmas. 2008. Cara Pemakaian Pupuk Biologi Agrobost. http://pupuksmsagrobost.blogspot.com/2008/06/pupuk-sms-agrobost-solusi-menujusukses.html [Diakses Juli 2014]. 
Rosmarkam, A. dan Nasih Widya Yuwono. 2002. Ilmu Kesuburan Tanah. Kanisius. Yogyakarta.

Setyowati. 2001. Skrining fitokimia dan identifikasi komponen utama ekstrak metanol kulit durian (Durio zibethinus Murr.) Varietas Petruk. Jurnal Seminar Nasional Kimia dan Pendidikan Kimia.

Suryawati, 2011. Jurnalistik Suatu Pengantar Teori dan Praktik. Ghalia Indonesia. Bogor.

Sutedjo, M. M. 2001. Pupuk dan Cara Pemupukan. Rineka Cipta. Jakarta.

Sutanto, R. 2006. Pertanian Organik. Kanisius. Yogyakarta. 